\title{
Two new Mycale (Naviculina) Gray (Mycalidae, Poecilosclerida, Demospongiae) from the Paulista Biogeographic Province (Southwestern Atlantic)
}

\author{
Cléa Lerner ${ }^{1}$ \\ Eduardo Hajdu ${ }^{2}$
}

\begin{abstract}
Two new Mycale (Naviculina) Gray, 1867 are described, M. (N.) arcuiris sp. n. and $M$. (N.) purpurata sp. n., from the Paulista Biogeographic Province (Southwestern Atlantic). They both occur in the São Sebastião Channel area (São Paulo state coast), the former extending its known distribution to "Arvoredo Marine Biological Reserve" (Santa Catarina state coast). The new species are sibling and differ from each other by a series of very small traits, the most notorious being live-color: yellow, orange, green, white, grey and beige, always light, in $M .(N$.) arcuiris $\mathbf{s p . ~} \mathbf{n}$. and bordeaux in $M$. (N.) purpurata sp. $\mathbf{n}$. Both species are compared with other known $M$. (Naviculina). Mycale (Aegogropila) hentscheli Sim \& Lee, 2001 is transferred to subgenus Naviculina and given a new name, viz. M. (N.) chungae nom. n., as the specific name was preoccupied by M. (Carmia) hentscheli Bergquist \& Fromont, 1988. An identification key for all the species hitherto assigned to the subgenus is provided. KEY WORDS. Porifera, taxonomy, Southwestern Atlantic, Mycale, Naviculina
\end{abstract}

GRAY (1867) erected Naviculina for sponges with "boat-shaped defensive spicules", the "naviculoid spiculum" sensu BOWERBANK (1864). The name has been overlooked ever since, until HOOPER \& WIEDENMAYER (1994), while revising the list of Australian sponges, considered Naviculina a valid taxon within the Mycalidae, and transferred Arenochalina Lendenfeld, 1887 to its junior synonymy. This view has been contested by HAJDU (1999), who argued that both taxa are diagnosed by distinct characters, thus deserving the status of valid, natural species groups within Mycale. Two new species pertaining to Mycale (Naviculina), the first records from the western Atlantic - Paulista Biogeographic Province (CoElHO \& SANTOS 1980; PALACIO 1982), are described here. An identification key for all the known M. (Naviculina) is provided.

\section{MATERIAL AND METHODS}

The collected samples were gathered through scuba diving along the coasts of the states of São Paulo and Santa Catarina, during an ongoing effort to survey the marine sponge biodiversity in these areas (Fig. 1). The São Sebastião Channel area (including the surroundings of São Sebastião Island) was sampled qualitatively

1) Museu de Ciências Naturais, Setor de Porifera, Fundação Zoobotânica do Rio Grande do Sul. Caixa Postal 1188, 90001-970 Porto Alegre, Rio Grande do Sul, Brasil.

E-mail: cblerner@portoweb.com.br

2) Museu Nacional, Departamento de Invertebrados, Universidade Federal do Rio de Janeiro.

Quinta da Boa Vista, 20940-040 Rio de Janeiro, Rio de Janeiro, Brasil.

E-mail: hajdu@acd.ufrj.br 


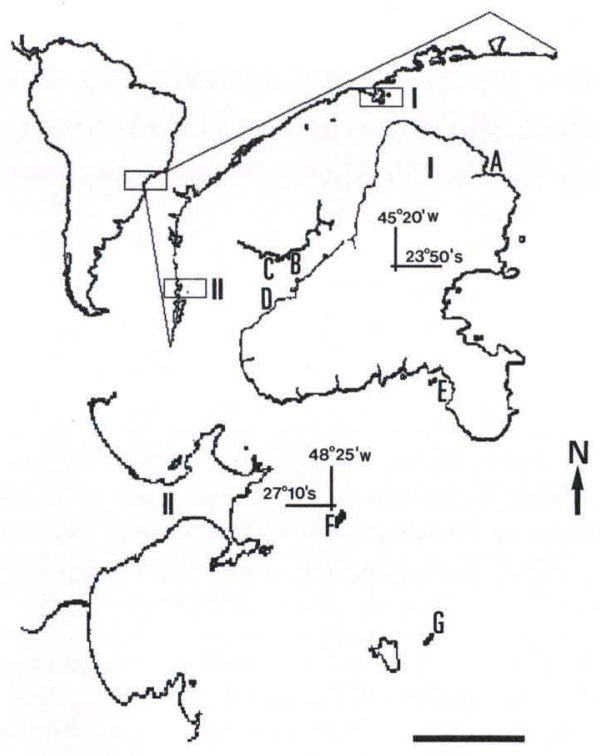

Fig.1. Map of South America indicating the southeastern/southern Brazilian region (Southwestern Atlantic). In detail, the localities and collection stations where specimens came from: (I) Ilha de São Sebastião, São Paulo: (A) Saco do Poço, (B) Ponta do Jarobá, (C) Itaçuce Islet, (D) small embayment between Veloso and São Pedro, (E) Garoupa Rock; (II) Porto Belo, Santa Catarina: (F) Ilha da Galé, (G) Parcel da Ilha Deserta. Scale bar $10 \mathrm{~km}$.

from 0 to $27 \mathrm{~m}$ depth. Specimens are deposited in the Porifera Collection of the Museu Nacional, Universidade Federal do Rio de Janeiro (MNRJ). Santa Catarina state specimens were collected at the "Arvoredo Marine Biological Reserve", between 4 and $18.8 \mathrm{~m}$ depth, and are deposited in the Porifera Collection of Museu de Ciências Naturais, Fundação Zoobotânica do Rio Grande do Sul (MCNPOR). Specimens were photographed in situ, and microscopic preparations made according to MOTHES-DE-MORAES (1985) e HAJDU (1994). Scanning electron microscopy was done partly in a Jeol JSM-35 from the ZMA, University of Amsterdam (Amsterdam, The Netherlands); partly in a Zeiss DSM-940 from the IB-USP (São Paulo, Brazil); partly in a Jeol JSM-5310 from the Departamento de Microscopia Eletrônica, UFRJ (Rio de Janeiro, Rio de Janeiro); and partly in a Jeol JSM-5200 from the MCN-FZB (Rio Grande do Sul, Brazil). The methodology for the obtention of SEM preparations follows CARBALLO \& HAJDU (1998). Spicule micrometries given in the text refer to minimum length - mean - maximum length/minimum width - mean - maximum width, unless stated otherwise.

\section{Comparative material}

Naviculina cliftoni Gray, 1867 (BMNH 1877.5.21.270, type slide - Freemantle, Australia).

Mycale diastrophochela Lévi, 1969 (MNHN-LBIM-D-CL 1447, holotype - Vema

Seamount, SE Atlantic). 
Mycale cleistochela Vacelet \& Vasseur, 1971 (MNHN-LBIM-D-VV 36, holotype - Tulear, Madagascar); MNHN-LBIM-D-VV 35 (det. J. Vacelet \& P. Vasseur, as ssp. flagellifer-Tulear, Madagascar).

Mycale aff. peculiaris Pulitzer-Finali, 1996 - ZMA 8512 (det. E.Hajdu \& R.W.M. van Soest - Sumbawa, Indonesia); ZMA 8896, 8897, 8917 (det. E. Hajdu \& R.W.M. van Soest - Tarupa Kecil, Indonesia).

Mycale obscura (CARTER 1882; BMNH 1881.10.21.318, holotype - Torres Str., Australia), BMNH 1881.10.21.318 (det. S. Ridley - Thursday Island, Torres Straits); BMNH 1925.11.1.732 (det. M.E. Shaw - Tasmania, Australia); SMF 1041 (det. E. Hentschel - Aru, Indonesia); ZMA 1602 (det. M. Burton Indonesia); ZMH-S 1670 (det. E.Hentschel - Shark's Bay, Australia).

Abbreviations used are: BMNH (The Natural History Museum, London, United Kingdom), MCN (Museu de Ciências Naturais, Fundação Zoobotânica do Rio Grande do Sul, Porto Alegre, Brazil), MCNPOR (MCN - Porifera Collection), MNHN-LBIM-D-CL (Muséum d'Histoire naturelle, Paris, France - Laboratoire de Biologie des Invertebrés Marins et Malacologie - leg. - Claude Lévi), MNHNLBIM-D-VV (Muséum d'Histoire naturelle, Paris, France-Laboratoire de Biologie des Invertebrés Marins et Malacologie - leg. - Jean Vacelet and Pierre Vasseur), MNRJ (Museu Nacional, Universidade Federal do Rio de Janeiro, Rio de Janeiro, Brazil), SMF (Senckenberg Museum, Frankfurt am Main, Germany), ZMA (Zoölogisch Museum, Amsterdam, The Netherlands), ZMH-S (Zoologisch Museum Hamburg - Schwämme, Hamburg, Germany).

\section{SYSTEMATICS}

\section{Poecilosclerida Topsent, 1928 Mycalina Hajdu, van Soest \& Hooper, 1994 Mycalidae Lundbeck, 1905} Mycale Gray, 1867

Diagnosis. Mycalidae with anisochelas.

\section{Mycale (Naviculina) Gray, 1867}

Diagnosis. Mycale with naviculichelae (palmate anisochelae with a complete or nearly so fusion of both frontal alae, falx markedly expanded along the shaft, and lateral alae of the head projecting backward and upward).

Remarks. HAJDU (1999) recognized five species worldwide assignable to $M$. (Naviculina), viz. M. (N.) cliftoni Gray, 1867 (type species), from Australia; M. (N.) obscura (Carter, 1882), from Indonesia and Australia; $M$. (N.) diastrophochela Lévi, 1969, from the Vema Seamount (SE Atlantic); M. (N.) cleistochela Vacelet \& Vasseur, 1971, from Madagascar; and $M$. (N.) peculiaris Pulitzer-Finali, 1996, from Papua New Guinea. The latter species is here transferred to Mycale (Aegogropila), thus stressing the reticulated nature of its ectosomal architecture and reinterpreted 
distinctive features of the morphology/ontogeny of its modified anisochelae, which do not conform to the pattern seen in proper naviculichelae sensu HAJDU (1999). A new term is here proposed for the anisochelae in $M$. (A.) peculiaris, viz. peculichelae. HAJDU's (1999) interpretation of a naviculichela is given in the diagnosis above, and found to be not entirely conforming to the chelae present in $M$. peculiaris, according both to illustrations presented by PULITZER-FINALI (1996) and on the study of additional material from the Zoologisch Museum Amsterdam (ZMA 8512, 8896, 8897, 8917), provisionally identified as $M$. aff. peculiaris. The modified chelae in $M$. peculiaris are tentatively defined below, pending a more thorough scrutiny of its morphology under SEM: palmate anisochelae with a complete or nearly so fusion of both frontal alae, falx markedly expanded along the shaft and frequently spined on its upper portion, lateral alae of the head projecting forward and upward.

Mycale (A.) hentscheli Sim \& Lee, 2001, from Korea, is transferred to $M$. (Naviculina). The name was preoccupied by M. (Carmia) hentscheli (Bergquist \& Fromont, 1988, as C. hentscheli), which characterises a secondary homonymy. A new name is proposed here for the Korean material described by SIM \& LEE (2001), viz. M. (N.) chungae nomen novum, in recognition of Prof. Chung Ja Sim's notorious contribution to our knowledge of Korean sponges. This taxonomic decision is taken in agreement with article 53.3 in ICZN (1999).

\section{Mycale (Naviculina) arcuiris sp. $\mathbf{n}$.}

Figs 2-4, 6-15, Tab. I

Material studied. Holotype, BRAZIL, São Paulo: MNRJ-773, Saco do Poço ( $23^{\circ} 45.658^{\prime}$ 'S-451․ $1462 \mathrm{~W}$, Ilha de São Sebastião, Ilhabela), $8 \mathrm{~m}$ depth, E. Hajdu leg., 09.I.1996. Paratypes: Brazil, São Paulo: MNRJ-263, Itaçuce Islet (23 49.890'S-45²6.558'W, off Praia de Barequeçaba, São Sebastião), 6m depth, E. Hajdu leg., 19.I.1996; MNRJ-362, Ponta do Jarobá (2349.676'S-45²5.278' W, São Sebastião Channel, São Sebastião), 0.5-2.5m depth, E. Hajdu \& G. Muricy leg., 26.I.1996; MNRJ-425, Ponta do Jarobá (2349.676' S-45²5.278'W, São Sebastião Channel, São Sebastião), ca. 2m depth, E. Hajdu leg., 23.VII.1996; MNRJ-1826,

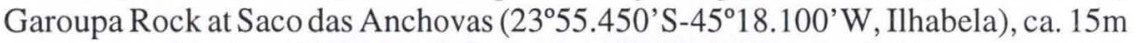
depth, E. Hajdu leg., 09.IX.1998. Santa Catarina State: Ilha da Galé (27 10.800'S4824.300'W): MCNPOR 3757, 4m depth, C.B. Lerner leg., 17.II.1998. Parcel da Ilha Deserta (submerged islet, $27^{\circ} 16.500^{\prime}$ S $-48^{\circ} 20.000^{\prime} \mathrm{W}$ ): MCNPOR 3983, 3984, 3987, 3990, 18-18.8m depth, C.B. Lerner leg., 23.II.1999.

Schyzotypes from holotype: ZMA 15832; MCN 4759.

Diagnosis. Mycale arcuiris sp. $\mathbf{n}$. is the only $M$. (Naviculina) to combine megascleres which are always smaller than $450 \mu \mathrm{m}$ long (means between 339 and $372 \mu \mathrm{m}$ ); anisochelae of normal palmate shape; naviculichelae which are often larger than $20 \mu \mathrm{m}$; and sigmas of the usual shape (non-flageliform), always separated into two distinct size categories, the larger ones between 35 and $69 \mu \mathrm{m}$ long (means around $50 \mu \mathrm{m}$ ), and the smaller ones near $10 \mu \mathrm{m}$ long. No toxas occur. 


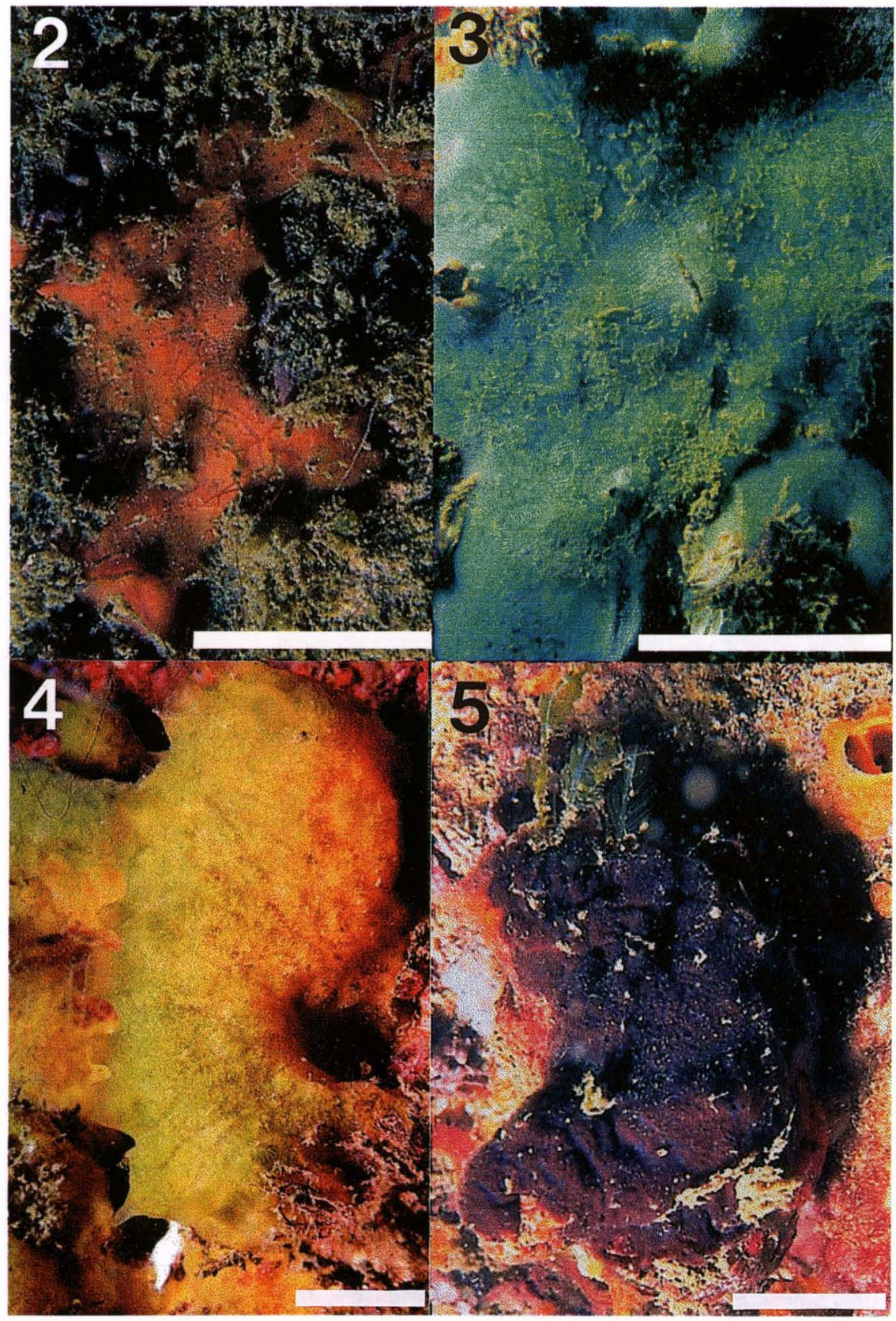

Figs 2-5. Underwater photographs. Mycale (Naviculina) arcuiris sp. n. (paratypes, alive, in situ): (2) specimen MNRJ 425; (3) specimen MNRJ 2999. Commonest live coloration at São Paulo State localities; (4) specimen MCN 3983; (5) Mycale (Naviculina) purpurata sp. n. (holotype, alive, in situ), specimen MNRJ 1671. Scale bar $2 \mathrm{~cm}$.

Revta bras. Zool. 19 (1): 109 - 122, 2002 
Description (Figs 2-4). Thinly or massively encrusting; directly attached to rocky substrate. Thinner specimens soft and fragile, thicker ones firm but compressible. Surface smooth, translucent, membranaceous. Subectosomal canals moderately visible. Area coverage up to 9 x $5 \mathrm{~cm}$. Oscula spread all over in low numbers; or on aligned, transparent, delicate chimney-like projections on the specimens' upper part (MCNPOR 3983, 3984, 3987, 3990). Live-color orange (MNRJ 425, 773), white (MNRJ 263), grey (MNRJ 362), light-green (MNRJ 263, 1826), beige (MCNPOR 3757) or greenish-yellow (MCNPOR 3983, 3984, 3987, 3990); preserved material white or whitish.

Skeleton (Figs 6-7). The ectosomal skeleton is composed of a neat, mostly triangular reticulation of paucispicular megasclere bundles (ca. 5 or less spicules across), to which some isolated megascleres are added strewn in confusion. It is situated on an easily detachable surface peel. Meshes are ca. 100 by $150 \mu \mathrm{m}$ wide, and may include pores (ca. $60 \mu \mathrm{m}$ in diameter). Spongin is not conspicuous, instead, anisochelae in rosettes (10-15 spicules, ca. $100 \mu \mathrm{m}$ in diameter), as well as sigmas-I are often arranged around the bundles, presumably helping to hold them fast. Naviculichelae, and sigmas-II are frequently observed inside the meshes spread all over in low densities. Specimen MNRJ-263 has tightly packed batches of sigmas-I in the subectosomal region, in no apparent relation to the disposition of megasclere bundles, and/or interpore spaces. Choanosomal skeleton. Plumose, with sinuous, ascending tracts of mycalostyles (28.5 to $66.5 \mu \mathrm{m}$ across) which diverge in tufts when approaching the sponge surface. Isolated mycalostyles strewn in confusion are seen among the main tracts, as well as rosettes of anisochelae, naviculichelae and sigmas spread randomly.

Spicules (Figs 8-15, Tab. I). Megascleres: straight, seldom mildly bent near the base, smooth mycalostyles; oval to roundish, slightly inflated base; apex abruptly sharpened, maybe telescoped. Microscleres: palmate anisochelae with straight shaft; naviculichelae with narrow, long frontal alae of the head, nearly fusing with feet, lateral alae of the head project backward and completely merge with shaft alongside; sigmas-I and -II delicate, smooth, sharp apices.

Ecology. This is a rare species and little can be said about its preferences. Its observed depth range goes from the shallowest infralittoral to some $19 \mathrm{~m}$, and specimens tend to occur mainly on high diversity vertical surfaces. In Santa Catarina, specimens occurred on photophilous habitats, with considerable water flow, at moderate depths (18-19 m). The thinly encrusting specimen was collected in a sheltered bay, at $4 \mathrm{~m}$ depth.

Etymology. The species is named after the plethora of live colours exhibited by the specimens collected ( $\mathrm{arcu}$, Latin for arch; iris, Latin for rainbow).

Remarks. Mycale (N.) arcuiris sp. n. differs from $M$. (N.) cleistochela by the former's possession of considerably smaller megascleres, sigmas-I and -II, and absence of toxas. It is set apart from $M$. (N.) cliftoni by the former's possession of anisochelae-I and sigmas-I. The new species is distinguished from Mycale (N.) diastrophochela by the former's larger anisochelae-I and possession of sigmas; and from Mycale ( $N$.) cleistochela flagellifer in result of the new species' much smaller megascleres, non flagelliform sigmas-I and absence of toxas. The new species is set apart from Mycale (N.) chungae nom. $\mathbf{n}$. by the former's possession of a single 


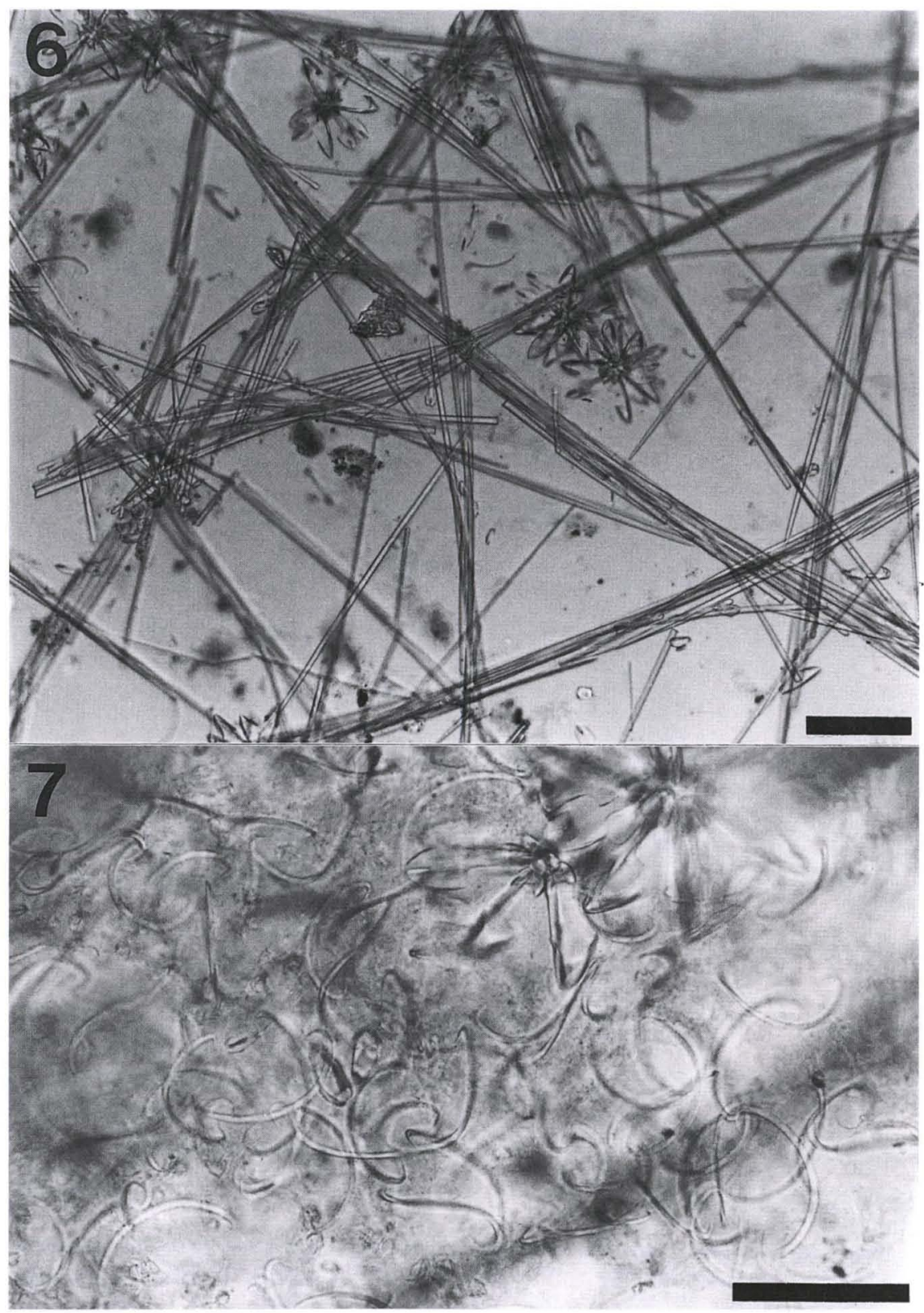

Figs 6-7. Mycale (Naviculina) arcuiris sp. n. (paratypes). (6) MNRJ 362, tangential section showing neat reticulation of paucispicular bundles of mycalostyles forming triangular or poligonal meshes. Anisochelae-I can be seen singly or in rosettes. Sigmas and naviculichelae can be seen too, but in smaller numbers. Scale bar $100 \mu \mathrm{m}$. (7) MNRJ 263, detail of (sub)ectosomal area showing a dense aggregation of sigmas-I. A rosette of anisochelae and a naviculichela can also be seen. Scale bar $50 \mu \mathrm{m}$. 
Table I. Comparative data on spicule dimensions of Mycale (N.) arcuiris sp. n., Mycale (N.) purpurata sp. $\mathbf{n}$. and other species of Mycale (Naviculina). Measures are expressed as smallest length - mean - largest length, unless stated otherwise. Measures are given in $\mu \mathrm{m} . \mathrm{N}=20$ for all the length measurements, and $\mathrm{N}=10$ for thickness measures, unless stated otherwise.

\begin{tabular}{|c|c|c|c|c|c|c|}
\hline & Mycalostyles 1 & Anisochelae 2 & Naviculichelae & Sigma-I & Sigma-IIToxas & Toxas \\
\hline \multicolumn{7}{|l|}{ M. arcuiris sp. $\mathrm{n}$. } \\
\hline MNRJ 773 & $280-346.2-372$ & $32-39.9-45$ & $13.5-18.5-23.8$ & 44-50.8-59 & $9-10.4-11.5$ & \\
\hline Holotype & $\begin{array}{l}2.3-4.6-6.3 \\
2.3-5.9-7.5\end{array}$ & $15-19.8-22$ & & $2-\underline{2.5}-3$ & & \\
\hline MNRJ 263 & $296-343.2-380$ & $44-48.3-55$ & $15-18.3-25$ & $45-49.6-58$ & $8.8-10.2-12$ & \\
\hline Paratype & $\begin{array}{l}1.8-4.3-6.5 \\
1.8-4.9-7.5\end{array}$ & $22-24.2-28$ & & $1.8-2.3-3$ & & \\
\hline MNRJ 362 & $320-\underline{353.6-398}$ & $42-46.7-55$ & $13-17.7-30$ & $44-48.9-54$ & $9.6-9.8-10.8$ & \\
\hline Paratype & $\begin{array}{l}2.4-5.8-7.2 \\
1.7-6.0-7.2\end{array}$ & $20-22.2-25$ & & $2-2.3-2.9$ & & \\
\hline MNRJ 425 & $330-351.9-369$ & $37-41.2-45$ & $15-18.5-24$ & $41-47.6-54$ & $9-12$ & \\
\hline Paratype & $\begin{array}{l}4-5.7-7 \\
3-6.3-7.4\end{array}$ & $19-20.7-22$ & & $2.2-2.5-2.9$ & $(\mathrm{~N}=3)$ & \\
\hline MNRJ 1826 & $305-351.3-380$ & $40-43.1-48$ & $18-\underline{21.8-28}$ & $40-49.4-55$ & $12.5-15$ & \\
\hline Paratype & $\begin{array}{l}5-7.1-8.8 \\
8-9.5-11.3\end{array}$ & $15-20.0-23$ & & & $(\mathrm{~N}=3)$ & \\
\hline MNRJ 2999 & $\begin{array}{c}305-\frac{358.5-395}{5-6-7.5} \\
3.8-6.3-8.8\end{array}$ & $\begin{array}{c}27.5-38-47.5 \\
10-14.9-25\end{array}$ & $15-20.6-25$ & $43-51.9-58$ & $10-11.9-13.8$ & \\
\hline MCNPOR 3757 & $314-339.3-371$ & $35-\underline{37.6-43}$ & $14-19.4-28$ & $35-\underline{44.9-51}$ & $9-10.8-14$ & \\
\hline Paratype & $\begin{array}{l}2.3-5.3-6.9 \\
2.3-5.1-6.9\end{array}$ & $15-16.8-20$ & & 2.3 & $(\mathrm{~N}=8)$ & \\
\hline MCNPOR 3983 & $333-358.6-409$ & $28-33,9-43$ & $16-22.9-30$ & $44-52.7-58$ & $9.2-10.4$ & \\
\hline Paratype & $\begin{array}{l}4.6-7.7-12 \\
2.3-\underline{6.6}-9.2\end{array}$ & $12-15.5-20$ & & 2.3 & $(\mathrm{~N}=3)$ & \\
\hline MCNPOR 3984 & $295-3572-399$ & $30-34.3-43$ & $18-21.9-28$ & $42-47.6-53$ & $10-11.3$ & \\
\hline Paratype & $\begin{array}{l}2.3-6.4-10 \\
2.3-6.2-9.2\end{array}$ & $13-16.0-20$ & & 2.3 & $(\mathrm{~N}=3)$ & \\
\hline MCNPOR 3987 & $304-362.1-399$ & $30-33.5-40$ & $16-\underline{22.1}-30$ & $48-54.0-62$ & $10-11-12.5$ & \\
\hline Paratype & $\begin{array}{l}4.6-8.0-11.5 \\
2.3-6.4-9.2\end{array}$ & $14-15.6-19$ & & 2.3 & $(\mathrm{~N}=10)$ & \\
\hline MCNPOR 3990 & $314-372.4-409$ & $28-32.8-40$ & $16-22.6-30$ & $46-56.4-69$ & $8.8-10.3-11.3$ & \\
\hline Paratype & $\begin{array}{l}4.6-6.6-9.2 \\
2.3-\underline{6.5}-9.2\end{array}$ & $13-15.8-19$ & & 2.3 & $(\mathrm{~N}=10)$ & \\
\hline \multicolumn{7}{|l|}{ M. purpurata sp. $\mathrm{n}$. } \\
\hline MNRJ 1671 & $240-296.8-330$ & $28-30.6-35$ & $17.5-21.7-25$ & & $9.5-10.9-11.8$ & \\
\hline Holotype & $\begin{array}{l}2.5-4.5-6.3 \\
3.8-5.0-6.3\end{array}$ & $10-14,3-15$ & $(N=100)$ & & & \\
\hline MNRJ 1669 & $265-296-345$ & $25-29.8-35$ & $20-22-28$ & & 10.5 & \\
\hline Paratype & $\begin{array}{l}3.8-4.8-6.3 \\
3.8-5.6-7.5\end{array}$ & $10-13,6-20$ & & & $(N=1)$ & \\
\hline Mycale chungae nom. $\mathbf{n}$. & $\begin{array}{l}\text { I. } 300-460 / 6-10 \\
\text { II. } 250-350 / 1-3\end{array}$ & $\begin{array}{l}\text { I. } 35-40 \\
\text { II. } 20-25 \\
\text { III. } 15-20\end{array}$ & $15-25$ & & & \\
\hline Mycale cleistochela & $480-640 / 5-18$ & $42-50$ & $\begin{array}{l}\text { I; } 20-30 \\
\text { II: } 12-18\end{array}$ & $70-90$ & $35-45$ & $\begin{array}{l}\text { I. } 30-60 \\
\text { II. } 15-20\end{array}$ \\
\hline $\begin{array}{l}\text { Mycale cliftonisensu } \\
\text { HAJDU (1999) }\end{array}$ & $\begin{array}{c}330-388 / 5-8 / \\
6-10\end{array}$ & & $\begin{array}{l}\text { I: } 12-22 \\
\text { II: ? }\end{array}$ & & $? 15$ & \\
\hline Mycale diastrophochela & $325-360$ & $30-32$ & $23-25$ & & & \\
\hline Mycale flagellifer & $480-640 / 5-18$ & $42-50$ & $\begin{array}{l}\text { I: } 20-30 \\
\text { II: } 12-18\end{array}$ & $65-75$ & $15-20$ & $16-25$ \\
\hline $\begin{array}{l}\text { Mycale obscura } \\
\text { [HENTSCHEL's (1911) } \\
\text { specimen remeasured] }\end{array}$ & $255-298 / 2.5-5$ & $32.5-36.3$ & $\begin{array}{l}\text { I: } 18.8-22.5 \\
\text { II: not found }\end{array}$ & $37.5-50$ & $10-12.5$ & \\
\hline
\end{tabular}

1) Measures expressed as smallest length - mean - largest length/smallest width of the head - mean - largest width of the head/ smallest width of the shaft - mean - largest width of the shaft (for literature data, width measures may have been taken at the stouter portion only, head or shaft). 2) Measures expressed as smallest total height - mean-largest total height/ smallest height of the the head - mean - largest height of the head.

Revta bras. Zool. 19 (1): 109 - 122, 2002 
category of megascleres and possession of sigmas-I. Besides, the new species' sigmas-II are nearly half the length of those in the Korean species. The new species is set apart from $M$. (N.) obscura by a set of slightly larger spicules, both megascleres and microscleres. Finally, it differs from the other new species described here, viz. $M$. (N.) purpurata sp. n., by the former's plethora of light-colours, opposed to the bordeaux live-colour in $M$. (N.) purpurata sp. n. Additionally, $M$. (N.) arcuiris sp. n. has slightly larger megascleres and anisochelae-I, and possesses sigmas-I, traits not exhibited by $M$. (N.) purpurata $\mathbf{s p .} \mathbf{n}$.
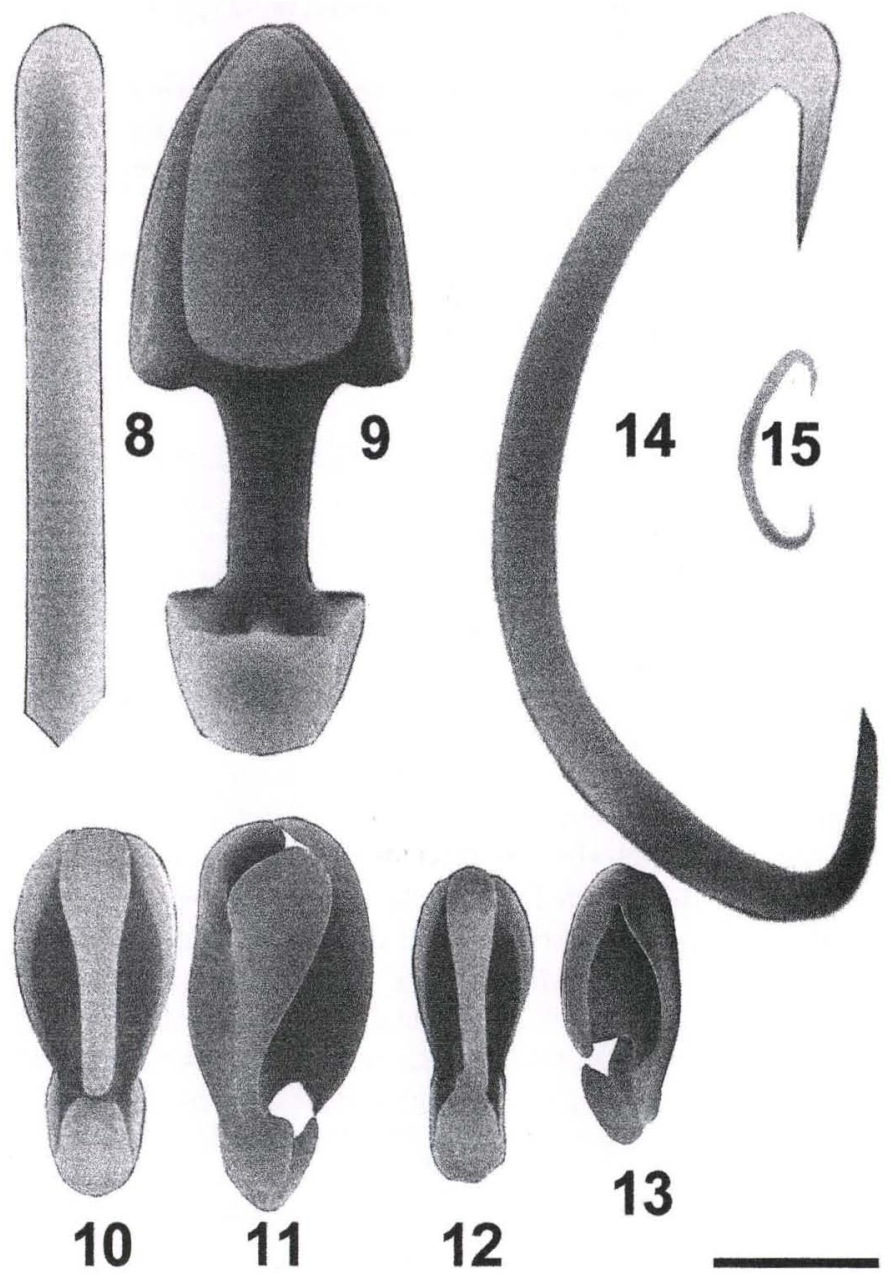

Figs 8-15. Mycale (Naviculina) arcuiris sp. n. (MNRJ 773, holotype), SEM micrographs of spicules, scale bar $10 \mu \mathrm{m}$. (8) Detail of basal termination (head) of the mycalostyle; (9) anisochela, frontal view; (10-13) naviculichela: (10) face view, (11) side view; (12) face view, (13) side view; (14) Sigma-I; (15) Sigma-II. 


\section{Mycale (Naviculina) purpurata sp. $\mathbf{n}$.}

Figs 5, 16-23, Tab. I

Material studied. Holotype, BRAZIL, São Paulo: MNRJ-1671, small embayment between Veloso and São Pedro (2352.863'S-4526.930'W, São Sebastião Channel, Ilhabela), ca. 11.5 m maximum depth, E. Hajdu leg., 21.IV.1998. Paratype, BRAZIL, São Paulo: MNRJ-1669, small embayment between Veloso and São Pedro ( $23^{\circ} 52.863^{\prime}$ S $-45^{\circ} 26.930^{\prime} \mathrm{W}$, São Sebastião Channel, Ilhabela), ca. 11.5 m maximum depth, E. Hajdu leg., 21.IV.1998. Schyzotypes from holotype: ZMA 16243; MCN 4759.

Diagnosis. Mycale purpurata $\mathbf{s p .} \mathbf{n}$. is the only M. (Naviculina) with megascleres smaller than $350 \mu \mathrm{m}$ (means around $300 \mu \mathrm{m}$ ); palmate anisochelae; naviculichelae which are often larger than $20 \mu \mathrm{m}$; and a small category of sigmas only, sometimes very rare, around $10 \mu \mathrm{m}$ long. No toxas occur.

Description (Fig. 5). Thinly encrusting on a solitary ascidian (possibly Microcosmus exasperatus - holotype) and on barnacles (paratype). Surface smooth, membranaceous, but folded to contour contracted substrate (holotype). Area coverage is $5.4 \times 3.6 \mathrm{~cm}$ in the holotype. Oscula are small $(1-2 \mathrm{~mm})$, inconspicuous, and scattered. Live-color purple (purpura).

Skeleton. The ectosomal skeleton is composed of a reticulation of paucispicular megasclere bundles, dense and confused at parts due to abundant criss-crossing spicules (holotype), or loose and sparse (paratype). It is situated on an easily detachable surface peel. Primary (5-7 spicules across) and secondary fibres (2-4 spicules across) can be recognized in the holotype. Meshes are frequently around $150 \mu \mathrm{m}$ across, and may include pores (ca. 20-50 $\mu \mathrm{m}$ in diameter). Spongin is inconspicuous, but rosettes of anisochelae (10-15 spicules, ca. $80 \mu \mathrm{m}$ in diameter) occur around the bundles and may help keep the architecture intact. Naviculichelae are often seen inside the meshes spread all over in low densities, as well as less common sigmas-II. Choanosomal skeleton. Plumose, with sinuous, ascending tracts of mycalostyles (30 to $100 \mu \mathrm{m}$ across) which diverge in tufts when approaching the surface.

Spicules. (Figs 16-23, Tab. I) Megascleres. Straight, seldom mildly bent near the central part, smooth mycalostyles; oval, slightly inflated base; apex abruptly sharpened, maybe telescoped. Microscleres. Palmate anisochelae with straight shaft. Naviculichelae with narrow, long frontal alae of the head, sometimes nearly fusing with feet, frequent basal, thin digitiform process present; lateral alae of the head project backward and completely merge with shaft alongside, basal parts may project further down and slightly overlap the alae of the foot. Sigmas-II delicate, smooth, sharp apices.

Ecology. Both specimens were found in a small embayment near the southern end of the São Sebastião Channel. Depth is moderate (ca. $12 \mathrm{~m}$ ), and water circulation very good. They were both collected on high diversity vertical walls of large rocks

Etymology. The name refers to the purple (purpurata, Latin for purple) live-colour of both specimens. 

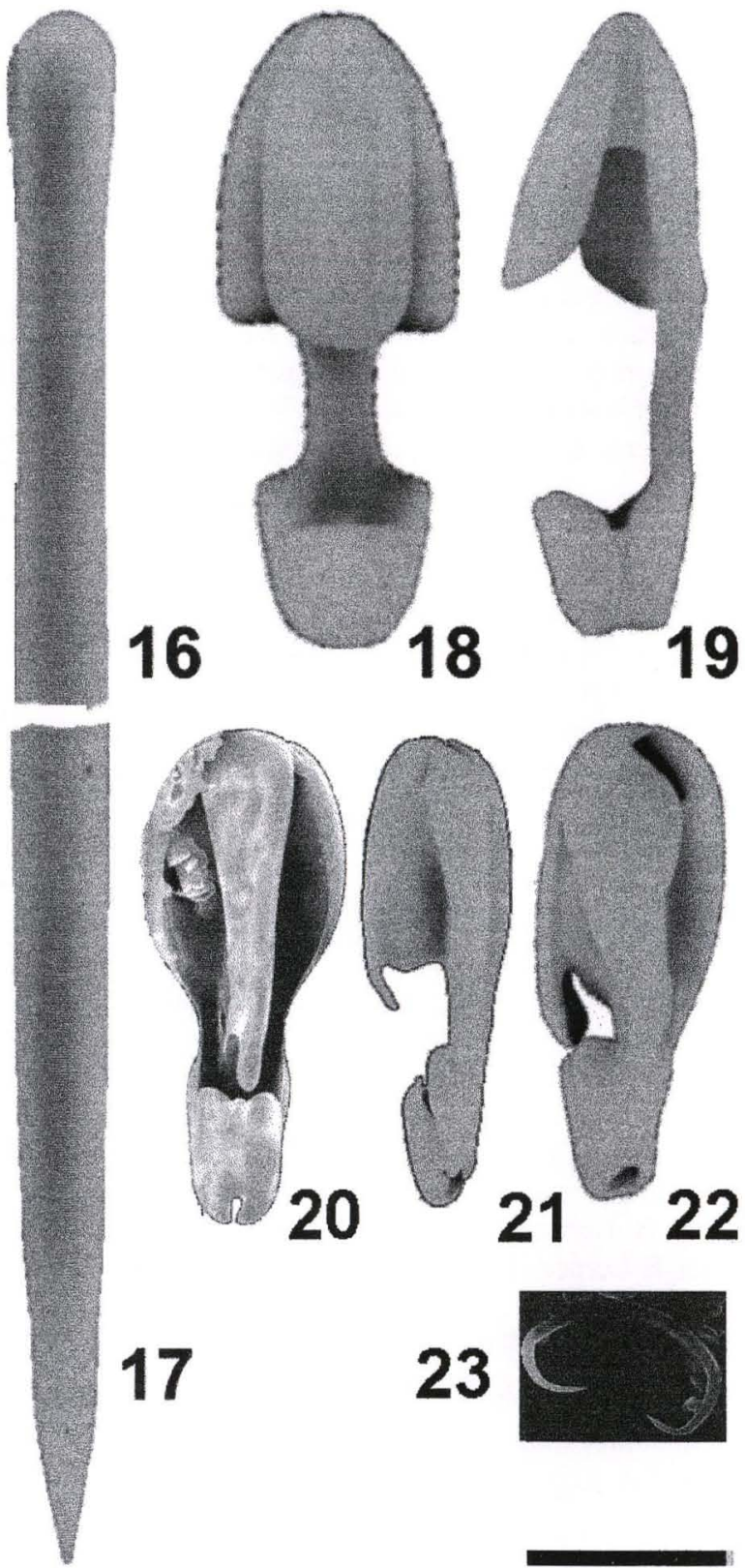

Figs 16-23. Mycale (Naviculina) purpurata sp. n. (MNRJ 1671, holotype), SEM micrographs of spicules, scale bar $10 \mu \mathrm{m}$. (16) Detail of basal termination (head) of the mycalostyle; (17) detail of apical termination of the mycalostyle; (18) anisochela, frontal view; (19) anisochela, side view; (20) naviculichela, face view; (21) naviculichelae, side view; (22) naviculichela, side view; (23) sigma-II. 
Remarks. Mycale (N.) purpurata sp. n. differs from M. (N.) cleistochela and $M$. (N.) c. flagellifer by the former's considerably smaller megascleres and anisochelae-I. In addition, it has no sigmas-I, a conspicuous trait in both madagascarian species. The new species differs from $M$. (N.) cliftoni by the former's possession of anisochelae-I and generally larger anisochelae-II. From $M$. (N.) diastrophochela it is distinguished by slightly larger megascleres and absence of sigmas in the brazilian species. Mycale ( $N$.) purpurata $\mathbf{s p .} \mathbf{n}$. differs from $M$. ( $N$.) chungae nomen novum by the former's possession of a single category of megascleres and much smaller sigmas-II. Mycale (N.) purpurata $\mathbf{s p .} \mathbf{n}$. is distinguished from $M$. (N.) obscura by the former's absence of sigmas-I. Both new species are distinguished from each other as argued in the remarks on $M$. (N.) arcuiris sp. n. above.

\section{BIOGEOGRAPHICAL REMARKS}

The recognition of a biogeographic province, transitional between a truly tropical Brazilian Province (North, Northeastern and part of Southeastern Brazil) and a truly subtropical Patagonian Province has been formally proposed by Coelho \& SANTOS (1980) and PAlacio (1982). This is known as the Paulista Biogeographic Province. The use advocated here does not stress the significance of a transitional zone per se, but rather, the fact that apparent endemics seem to be common in the area stretching from Cabo Frio to Santa Catarina (e.g. $M$. arcuiris sp. n.; Aplysina caissara Pinheiro \& Hajdu, 2001; Petromica citrina Muricy; Hadju; Minervino; Madeira \& Peixinho, 2001), even if more restricted (but congruent) geographically (e.g. Provisional endemics to the Cabo Frio region - Arenosclera brasiliensis Muricy \& Ribeiro, 1999; Callyspongia pseudotoxa Muricy \& Ribeiro, 1999; Dysidea robusta Vilanova \& Muricy, 2001. Provisional endemics to the São Sebastião channel region - M. purpurata sp. n.; M. lilianae Carballo \& Hajdu, 1998; Desmanthus meandroides van Soest \& Hajdu, 2000; Halichondria cebimarensis Carvalho \& Hajdu, 2001; H. migottea Carvalho \& Hajdu, 2001; H. sulfurea Carvalho \& Hajdu, 2001; H. tenebrica Carvalho \& Hajdu, 2001. Provisional endemics to the Santa Catarina region -Haliclona mammillaris Mothes \& Lerner, 1994; H. lilaceus Mothes \& Lerner, 1994; H. catarinensis Mothes \& Lerner, 1994).

\section{Identification key for the species of Mycale (Naviculina) known worldwide [M. obscura sensu HENTSCHEL (1911)]}

1. Chelae are naviculichelae only ....................... cliftoni

- Chelae are naviculichelae plus normal palmate anisochelae . ........... 2

2. Megascleres larger than $500 \mu \mathrm{m}$ common ................... 3

- Megascleres mostly smaller than $400 \mu \mathrm{m} \ldots \ldots \ldots \ldots \ldots \ldots \ldots \ldots \ldots$

3. Larger sigmas flagelliform, smaller ones only $15-20 \mu \mathrm{m}$ long, toxas in a single

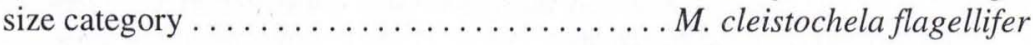

- Larger sigmas of normal shape, 70-90 $\mu \mathrm{m}$ long; smaller ones 35-45 $\mu \mathrm{m}$ long, toxas in two size categories . ........................ cleistochela 


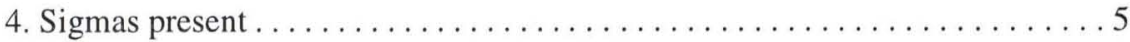

- No sigmas ............................... diastrophochela

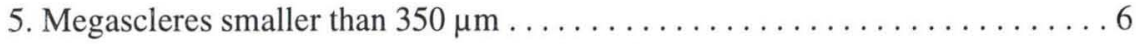

- Megascleres frequently larger than $350 \mu \mathrm{m} \ldots \ldots \ldots \ldots \ldots \ldots \ldots \ldots$

6. Sigmas of a single size category around $10 \mu \mathrm{m}$ long ......... purpurata $\mathbf{s p .} \mathbf{n}$. - Sigmas in two size categories (I: 36 , II: 8-9) . . . . . . . . . . obscura

7. Sigmas in two size categories, sigmas-I frequently over $50 \mu \mathrm{m} \ldots \ldots \ldots \ldots \ldots$ M. arcuiris sp. $\mathbf{n}$.

- Sigmas in a single size category smaller than $30 \mu \mathrm{m} . . . M$. (N.) chungae nom. $\mathbf{n}$.

ACKNOWLEDGEMENTS. R.W.M. van Soest and D. Platvoet (ZMA-JEOL); A. Ribeiro, M.V. Cruz and E. Mattos (USP-ZEISS); M. Attias and N. Rodrigues (UFRJ-JEOL); C.J. Mansan, M. Spadoni and L.M.G. Tavares (MCN/FZB-JEOL) are thanked for the provision of SEM facilities and technical support in SEM operation. C. Lerner is a $\mathrm{PhD}$ student at Universidade de São Paulo with a PhD Fellowship from Fundação de Amparo à Pesquisa do Estado de São Paulo (FAPESP, São Paulo state, Brazil, Proc. 96/11786-8). E. Hajdu is thankful to Coordenadoria de Aperfeiçoamento de Pessoal de Nível Superior (CAPES) for a travel grant, to Conselho Nacional de Desenvolvimento Científico e Tecnológico (CNPq) for a research fellowship and travel grant, to Fundação Carlos Chagas Filho de Amparo à Pesquisa do Estado do Rio de Janeiro (FAPERJ) for research and travel grants, to FAPESP for a research grant, and to Fundação Universitária José Bonifácio (FUJB/UFRJ) for an infrastructure grant for the Departamento de Invertebrados, Museu Nacional/UFRJ.

\section{REFERENCES}

Bowerbank, J.S. 1864. A monograph of the British Spongiadae. London, Ray Soc., vol. 1, XX+290p. CARballo, J.L. \& E. Hajdu. 1998. Micromorphology in Mycale taxonomy (Mycalidae, Poecilosclerida, Demospongiae), with the description of two new micracanthoxea-bearing species. Contr. Zool. 67 (3): $187-95$.

CARTER, H.J. 1882. Some sponges from the West Indies and Acapulco in the Liverpool Free Museum, described with general and classificatory remarks. Ann. Mag. Nat. Hist. (5) 9: 266-301, 346-368.

Coelho, P.A. \& Santos, M.F.B.A. Dos. 1980. Zoogeografia marinha do Brasil. I. Considerações gerais sobre o método e aplicação a um grupo de crustáceos (Paguros: Crustacea Decapoda, Super-famílias Paguroidea e Coenobitoidea). Bol. Inst. Oceanogr., São Paulo, 29(2): 139-144.

GRAY, J.E. 1867. Notes on the arrangement of sponges, with the description of some new genera. Proc. Zool. Soc. London 1867: 492-558.

HaJdu, E. 1994. A phylogenetic interpretation of hamacanthids (Demospongiae, Porifera) with a redescription of Hamacantha popana (De Laubenfels, 1935). Jour. Zool. 232: 61-77.

- 1999. Toward a phylogenetic classification of the Mycalids with anisochelae (Demospongiae: Poecilosclerida), and comments on the status of Naviculina Gray, 1867. Mem. Queens. Mus. 44: 225-238.

Hentschel, E. 1911. Tetraxonida 2. Teil. In: W. Michaelsen \& R. Hartmeyer (Eds). Die Fauna Südwest-Australiens 3 (10): 277-393.

Hooper, J.N.A. \& F. WiedenMayer. 1994. Porifera, p. 1-624. In: A. Wells (Ed.). Zoological Catalogue of Australia. Melbourne, CSIRO, vol. 12. 
ICZN. 1999. International Code of Zoological Nomenclature. Trust for Zoological Nomenclature, London, 304p.

Mothes-DE-Moraes, B. 1985. Sponges collected by the Oxford Diving Expedition, to the Cabo Frio Upwelling Area (Rio de Janeiro, Brasil). Stud. Neotrop. Fauna Environ. 20 (4): 227-237.

PALACIO, F.J. 1982. Revisión zoogeográfica marina del sur del Brasil. Bol. Inst. Oceanogr. Univ. São Paulo 31 (1): 69-92.

Pulitzer-Finali, G. 1996. Sponges from the Bismark Sea. Boll. Mus. Ist. Biol. Univ. Genova 60-61: 101-138.

SiM, C.J. \& K.J. LEE. 2001. Two new species of the genus Mycale (Poecilosclerida: Mycalidae) from Korea. Korean Jour. Biol. Sci. 5: 25-29.

Recebido em 15.XII.2000; aceito em 01.II.2002. 